132

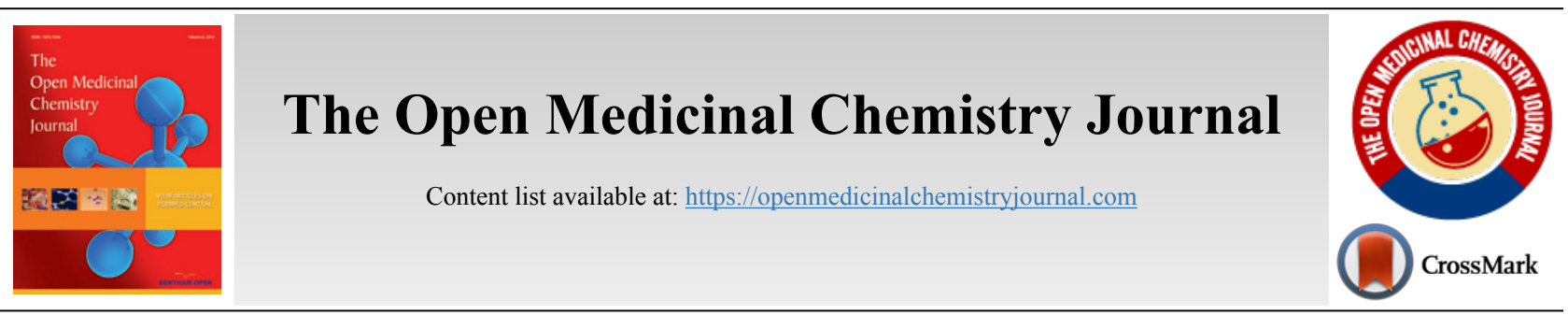

RESEARCH ARTICLE

\title{
Anti-diabetic Effect of Acridocarpus Orientalis
}

Mohamed Lotfy ${ }^{1}$, Taoufik S. Ksiksi ${ }^{1}$, Abdul Rasheed Palakkot ${ }^{1}$, Crystal M. D’Souza ${ }^{2}$, Sahar Mohsin ${ }^{2}$ and Ernest A. Adeghate ${ }^{2, *}$

${ }^{\prime}$ Department of Biology, College of Science, United Arab Emirates University, Al Ain, United Arab Emirates

${ }^{2}$ Department of Anatomy, College of Medicine \& Health Sciences, United Arab Emirates University, Al Ain, United Arab Emirates

\begin{abstract}
:
Background:

Acridocarpus orientalis (AO) is a medicinal herb indigenous to tropical and subtropical Africa, Arabian Peninsula, and New Caledonia with reported anti-inflammatory and antioxidant properties.

Objective:

To determine whether AO has any beneficial effects on diabetes-induced metabolic parameters in rats.

Materials and Methods:

Diabetes mellitus was induced in male Wistar rats by streptozotocin. Diabetic rats were treated with three doses of AO extract (50, 100 , and 200 $\mathrm{mg} / \mathrm{kg} \mathrm{BW}$ ) for 30 days. Kidney, liver, and pancreatic tissue samples were processed for histopathology to determine the effect of AO on the cells of these organs. The effect of AO on pancreatic islet cells and serum insulin levels was also examined using immunohistochemistry and enzymelinked immunosorbent assay techniques, respectively.

Results:

AO $(100 \mathrm{mg} / \mathrm{kg} \mathrm{BW})$ caused a marked reduction in blood glucose levels in diabetic rats compared to diabetic control on day 10 of the study. Moreover, AO $(200 \mathrm{mg} / \mathrm{kg} \mathrm{BW})$ increased the number of insulin-positive cells with a concomitant reduction in the number of glucagonimmunoreactive cells in pancreatic islets. AO $(100 \mathrm{mg} / \mathrm{kg})$ also increased the serum level of superoxide dismutase significantly. Although the administration of AO was able to significantly decrease the diabetes-associated increases in serum creatinine and bilirubin levels, it had no effect on blood urea nitrogen, serum aspartate, or alanine aminotransferase levels. Histopathological examination showed that AO has no toxic effect on the structure of the pancreas, liver, and kidney.

Conclusion:

Our findings showed that AO could alleviate some complications of diabetes mellitus.
\end{abstract}

Keywords: Acridocarpus orientalis, Antioxidant, Diabetes mellitus, Pancreas, Immunohistochemistry, Morin, Polyphenols, Flavonoids.

\begin{tabular}{|l|l|l|l|}
\hline Article History & Received: June 12, 2020 & Revised: September 18, 2020 & Accepted: September 22, 2020
\end{tabular}

\section{INTRODUCTION}

Diabetes Mellitus (DM) is a chronic endocrine disease with a high prevalence in urban populations. The number of people with DM is expected to reach 552 million cases by the year 2030, according to the International Diabetes Federation [1]. $\mathrm{DM}$ is caused by several genetic and environmental factors. It is associated with high blood glucose levels because of dysfu-

* Address correspondence to this author at Department of Anatomy, College of Medicine \& Health Sciences, United Arab Emirates University, P.O. Box 17666, Al Ain, United Arab Emirates; E-mail: eadeghate@uaeu.ac.ae nctional insulin secretion or cellular resistance to insulin binding [2]. Three main types of DM have been identified. Type $1 \mathrm{DM}$ is associated with the near destruction of pancreatic beta cells of the endocrine pancreas, leading to the secretion of a low and inadequate quantity of insulin. In contrast, type $2 \mathrm{DM}$ is associated with a sluggish lifestyle, unhealthy diet, obesity, adverse environmental factors such as drugs, viral infection, and genetic disorders [3, 4]. The other major type of DM is referred to as gestational diabetes, which occurs in a subtle form during pregnancy. Women with gestational DM may eventually develop overt DM after 
parturition [5]. Chronic untreated hyperglycemia induces oxidative stress [6], leading to the development of many macro- and micro-vascular complications such as cardiac diseases, retinopathy, neuropathy, and nephropathy [7 - 9]. All of these complications play a role in the high morbidity and mortality seen in patients with DM [10]. The short and longterm complications of DM and the associated signs and symptoms have indeed created a severe burden on health care providers worldwide [10]. Since the prevalence of DM will continue to rise as reported in a previous study [1], the need to manage DM, and its complications becomes even more important.

In addition, the need to discover a less expensive way in the treatment of DM fits into this endeavor. Herbal medicine is cost effective and it is one of the oldest traditional ways for the treatment of many diseases, including DM. Herbal medicine uses a natural source of medication for the treatment of diseases with the added advantage of easy availability and simplicity. Many of the herbs can be easily cultivated. Some of the herbs may come with reduced side effects when compared to pharmaceutical drugs. It has been estimated that about 80 percent of people worldwide are using herbal medicine in curing a variety of diseases [11]. Moreover, a large number of pharmaceutical drugs actually originated from natural plants [12].

Acridocarpus orientalis (AO) A. Juss (genus: Acridocarpus; family: Malpighiaceae) is one of the folk medicinal plants that have been used in the treatment of many diseases, such as cancer. AO is one of several herbs used to treat various illnesses in the Middle East. Although it has been reported that $\mathrm{AO}$ has anti-inflammatory and antioxidant properties [13], the effect of $\mathrm{AO}$ on a metabolic disease such as diabetes mellitus has not been investigated. AO is a flowering tropical plant, found in Africa, Asia and the Middle East.

The phytochemical analysis of AO extracts showed that it has many ingredients, such as; tannins, phenols, saponins and flavonoids compounds with antioxidant activities [13, 14].

The role of AO in mitigating the signs and symptoms of diabetes mellitus has not been elucidated. Since it is also well known that some herbal medication may cause harmful side effects [15] than curing the disease itself, it is important to determine whether a given herbal plant is toxic to major parenchymal organs such as the liver, kidney, and pancreas. Since the liver is the detoxification center of the body [16], an ideal drug, therefore, whether it is a herb or a synthetic preparation, should not be toxic to the liver or cause hepatic pathology that will effectively incapacitate its function.

In the present study, we hypothesized that the ethanol extract of AO increases the number of pancreatic beta cells, body weight, insulin level and reduces hyperglycemia in an animal model of diabetes. This hypothesis is based on reports that AO contains a high level of the plant antioxidant, polyphenols [13]. Recent reports have also shown that AO contains morin, a flavonol antioxidant [14]. We also wanted to clarify whether AO causes histopathological changes or has protective effects in the liver, kidney, and pancreas after the onset of diabetes.

\section{MATERIALS AND METHODS}

\subsection{Reagents and Antibodies}

Streptozotocin was purchased from Sigma-Aldrich (MO, USA; purity: $\geq 98 \%$ by HPLC). Insulin and glucagon primary and their respective secondary antibodies were purchased from Santa Cruz Biotechnology (CA, USA). Rat insulin ultrasensitive ELISA kits are products of Millipore (MO, USA).

\subsection{Experimental Animals}

In this study, 3 month-old male Wistar rats weighing $250 \mathrm{~g}$ and bred at the College of Medicine and Health Sciences (CMHS), United Arab Emirates University, were used. All rats were housed at a temperature of $25^{\circ} \mathrm{C}$ and humidity-regulated animal facility with a cycle of $12 \mathrm{~h}$ light $/ 12 \mathrm{~h}$ darkness. The animals received rodent feed and water ad libitum. The CMHS's Animal Research Group guidelines for the care and use of laboratory animals were followed (Ethical clearance number: A2-R07).

\subsection{Rodent Model of Diabetes Mellitus}

Diabetes mellitus (DM) was induced in male Wistar rats by a single intraperitoneal administration of streptozotocin (STZ, Sigma-Aldrich, MO, USA) at $60 \mathrm{mg} / \mathrm{kg}$ body weight $[17,18]$. Age- and gender-matched, non-diabetic control Wistar rats were treated with citrate buffer solution only. Blood glucose levels were tested on the tail vein using Optium Xceed Glucometer (Abbott Laboratories, IL, USA) five days after treatment with either STZ or citrate buffer solution. Animals with a $\geq 300 \mathrm{mg} / \mathrm{dl}$ fasting blood glucose level were selected for AO treated and untreated diabetic groups. Diabetic $(n=6)$ and non-diabetic control (normal, $\mathrm{n}=6$ ) rats received daily oral gavage of Acridocarpus orientalis extracts of either 50,100, or $200 \mathrm{mg} / \mathrm{kg}$ body weight for 30 days. In addition, one diabetic group received a daily dose of glibenclamide at $0.25 \mathrm{mg} / \mathrm{kg}$ body weight (BW) according to a previously reported dosage regimen [19]. Two other groups, untreated diabetic and normal control rats, were treated with only saline solution for the same duration of time. The total body weight and fasting blood glucose level of each rat for each group were recorded every 10 days. All measurements except BW and fasting blood glucose level were taken at the end of the experimental period.

\subsection{Plant Material and Preparation of Extract}

Aerial samples of AO (Acridocarpus orientalis) A. Juss. (Genus: Acridocarpus, Family: Malpighiaceae, local name: qafas) were collected from Jabal Hafeet (Al Ain, UAE, N 24.19, E 55.62), washed, air-dried and then stored in darkness at room temperature. The aerial samples retrieved were verified and deposited at the Herbarium of the Department of Biology, College of Science, UAE University, Al Ain. The aerial samples of AO were crushed, filtered, and the components were extracted three times with fresh ethanol at room temperature for a period of $12 \mathrm{~h}$. The ethanolic phase of the extraction was recovered, dried at $40^{\circ} \mathrm{C}$ by rotary evaporator, and lyophilized according to a previously reported method [13]. Lyophilized extracts were stored in the dark at $4^{\circ} \mathrm{C}$. 


\subsection{Body Weight, Fasting Blood Glucose Measurement and Intraperitoneal Glucose Tolerance Test}

The weight of normal and diabetic rats was measured every 10 days using the Sartorius scale (Goettingen, Germany). The fasting blood glucose level in the tail vein was recorded every ten days for each individual rat in all groups after an overnight fast.

Intraperitoneal Glucose Tolerance Test (IPGTT) was performed in normal and diabetic rats at the end of the experimental period after fasting the animals for $18 \mathrm{~h}$. Each rat from all of the four groups was given an intraperitoneal glucose load of $2 \mathrm{~g} / \mathrm{kg}$ BW according to a previously published procedure [20]. Blood glucose levels were taken at zero time (before glucose load), 30, 60, and $120 \mathrm{~min}$ after intraperitoneally delivered glucose load.

\subsection{Tissue and Blood Collection and Tissue Processing}

At the end of the experiment, all rats from all groups were subjected to general anesthesia using diethyl ether. Following decapitation, whole blood was collected into vacutainer tubes. The pancreas, liver, and kidney tissue samples were expeditiously removed, and stored for pathohistological investigations according to a previously reported method [21].

\subsection{Light Microscopy of the Pancreas, Liver and Kidney}

The isolated pancreatic, liver and kidney tissue fragments from each rat in each group were trimmed free of connective tissues and processed for hematoxylin and eosin (H \& E) staining according to previously reported methods [22, 23].

\subsection{Immunofluorescence Study}

Pancreatic tissue samples from treated and untreated normal and diabetic rats were trimmed free of connective tissues and processed for immunohistochemistry using a previously described method [18], employing antibodies against insulin and glucagon. Briefly, pancreatic tissue fragments were fixed, embedded in liquid paraffin and later processed for insulin and glucagon double-labelling immunofluorescence study according to a previously described technique [20,24], using antibodies against insulin and glucagon.

\subsection{Morphometric Analysis of Pancreatic Islet Cells}

The percentage distribution of pancreatic alpha (glucagonpositive) and beta (insulin-positive) cells was examined using Image J Software (NIH, MA, USA). We counted the total number of either insulin or glucagon positive cells compared to the total number of cells in the whole islet in accordance with a previously reported morphometric method [18].

\subsection{Serum Insulin}

The serum insulin level was determined by using a commercial kit (Millipore, MO, USA). All values were expressed as $\mathrm{ng} / \mathrm{ml}$. Samples were prepared for the determination of insulin using methods reported by Adeghate et al. [25].

\subsection{Measurement of Antioxidant Activity}

The activity of the anti-oxidative enzyme, superoxide dismutase (SOD), which converts superoxide anion $\left(\mathrm{O}_{2}{ }^{-}\right)$into hydrogen peroxide and harmless molecular oxygen, was measured using SOD Assay Kit-WST (Sigma-Aldrich, MO, USA). Measurement of antioxidant activity was performed according to a recently reported method [26].

\subsection{Biochemical Analysis}

Serum levels of the following parameters were determined using Cobas biochemical analyzer (Roche, Rotkreuz, Switzerland): aspartate aminotransferase, alanine aminotransferase, creatinine, bilirubin, creatinine, and blood urea nitrogen [27].

\subsection{Statistical Analysis}

All values were calculated as mean \pm standard error of the mean (SEM). ANOVA test was used to determine the significance between different groups. SPSS Statistical Analysis Software was used for statistical analysis. A $p$ value of $\leq 0.05$ was taken as a reference for significance.

\section{RESULTS}

\subsection{Body Weight, Glucose Level and Glucose Handling}

Normal control rats showed a remarkable weight gain $(\mathrm{p}<$ 0.05 ) when compared to AO- and glibenclamide-treated and untreated diabetic rats (Fig. 1a). The weight gain observed in treated diabetic groups was not significantly different 30 days after the induction of diabetes. Fasting blood glucose level was significantly $(p<0.05)$ higher in treated and untreated diabetic rats compared to non-diabetic controls. It is worth noting, however, that diabetic rats treated with either a $100 \mathrm{mg} / \mathrm{kg}$ body weight of $\mathrm{AO}$ or glibenclamide $(0.25 \mathrm{mg} / \mathrm{kg}$ body weight $)$ showed a significant $(p<0.05)$ reduction in blood glucose level 10 days after the induction of diabetes when compared to untreated diabetic rats (Fig. 1b).

Intraperitoneal Glucose Tolerance Test (IPGTT) showed that blood glucose levels of treated and untreated diabetic rats at $0,30,60$, and $120 \mathrm{~min}$ after glucose load were markedly $(\mathrm{p}<$ 0.05 ) higher when compared to non-diabetic control (Fig. 1c). 

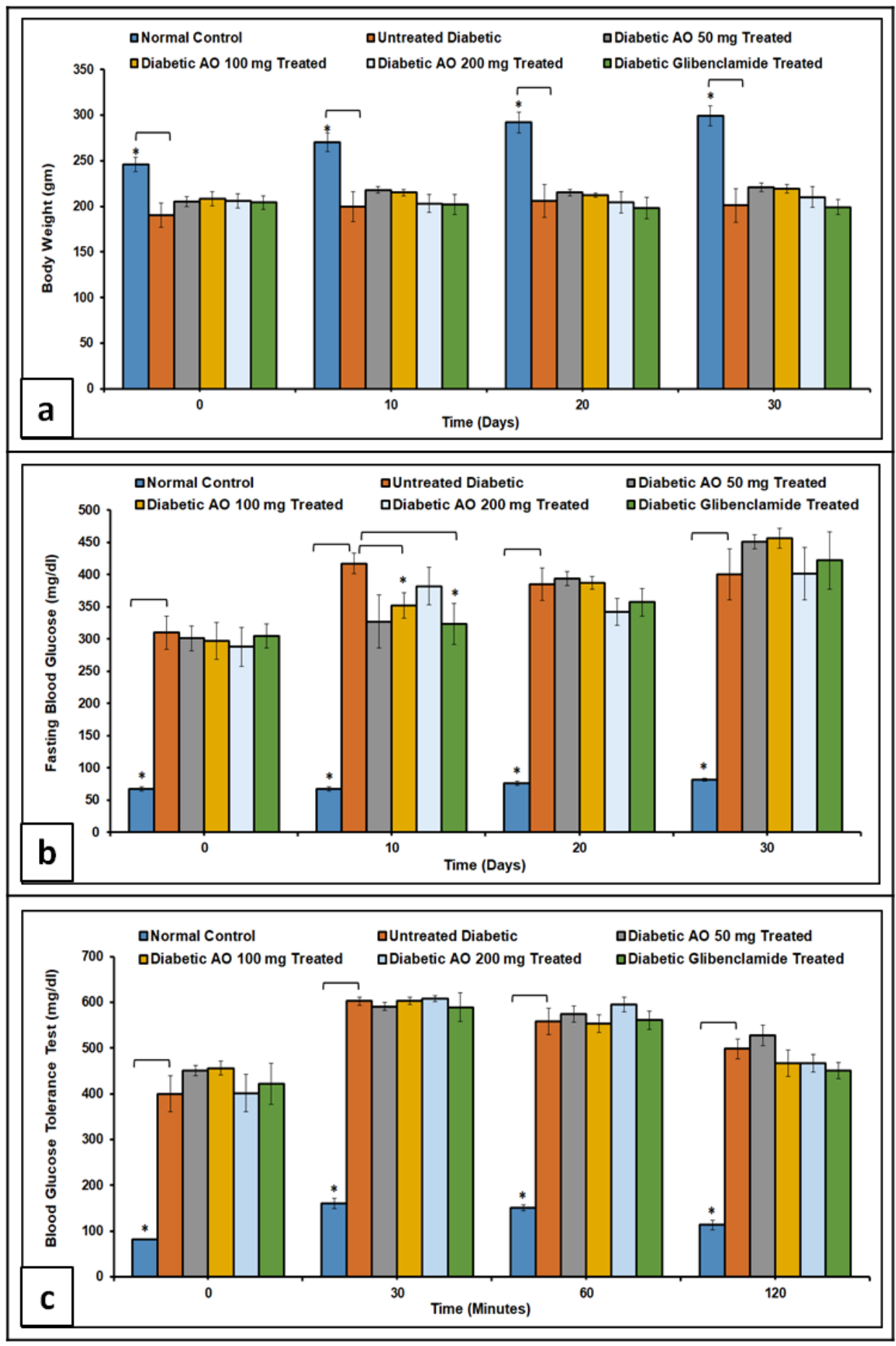

Fig. (1). Time-course graphs depicting the effect of Acridocarpus orientalis (AO) treatment on, (a) total body weight, (b) blood glucose levels, and (c) Intra-peritoneal Glucose Tolerance Test (IPGTT) in normal, untreated diabetic, and AO-treated diabetic rats. Note that the total body weight of non-diabetic control rats is significantly higher than that of AO-treated and untreated diabetic rats. Blood glucose level is markedly higher in AOtreated and untreated diabetic rats compared to non-diabetic controls. At day 10, the glucose level of AO-treated diabetic rats is significantly lower when compared to untreated diabetics. Data are presented as: $m e a n \pm S E M, n=6 . * p<0.05$.

\subsection{Distribution of Insulin- and Glucagon-positive Cells in Pancreatic Islets}

Double-labelling immunofluorescence method was used to determine the localization of insulin-positive and glucagonpositive cells in the islets of normal, treated and untreated diabetic rats (Fig. 2). The results showed that insulin-positive cells are located in the central part of the islet of normal control with glucagon-immunoreactive cells placed peripherally. The islets of untreated diabetic rats contain fewer insulin-positive cells but more of glucagon-positive cells when compared to AO-treated rats. It is worth noting that the number of insulinpositive cells increased significantly $(p<0.05)$ with a 
concomitant reduction in the number of glucagon-producing alpha cells in diabetic rats treated with either AO (100, 200 $\mathrm{mg} / \mathrm{kg}$ body weight) or glibenclamide $(0.25 \mathrm{mg} / \mathrm{kg}$ body weight) when compared with untreated diabetic rats (Fig. 3).
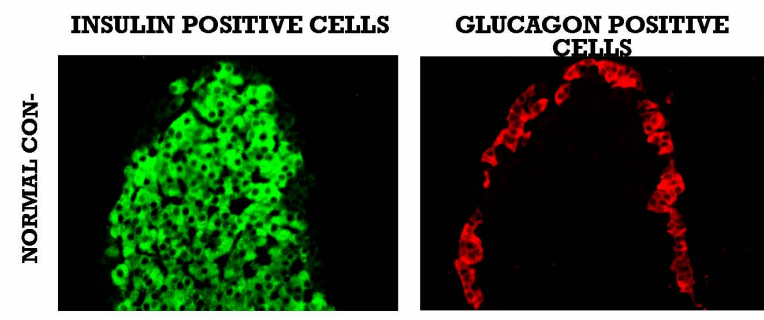

MERGED CELLS
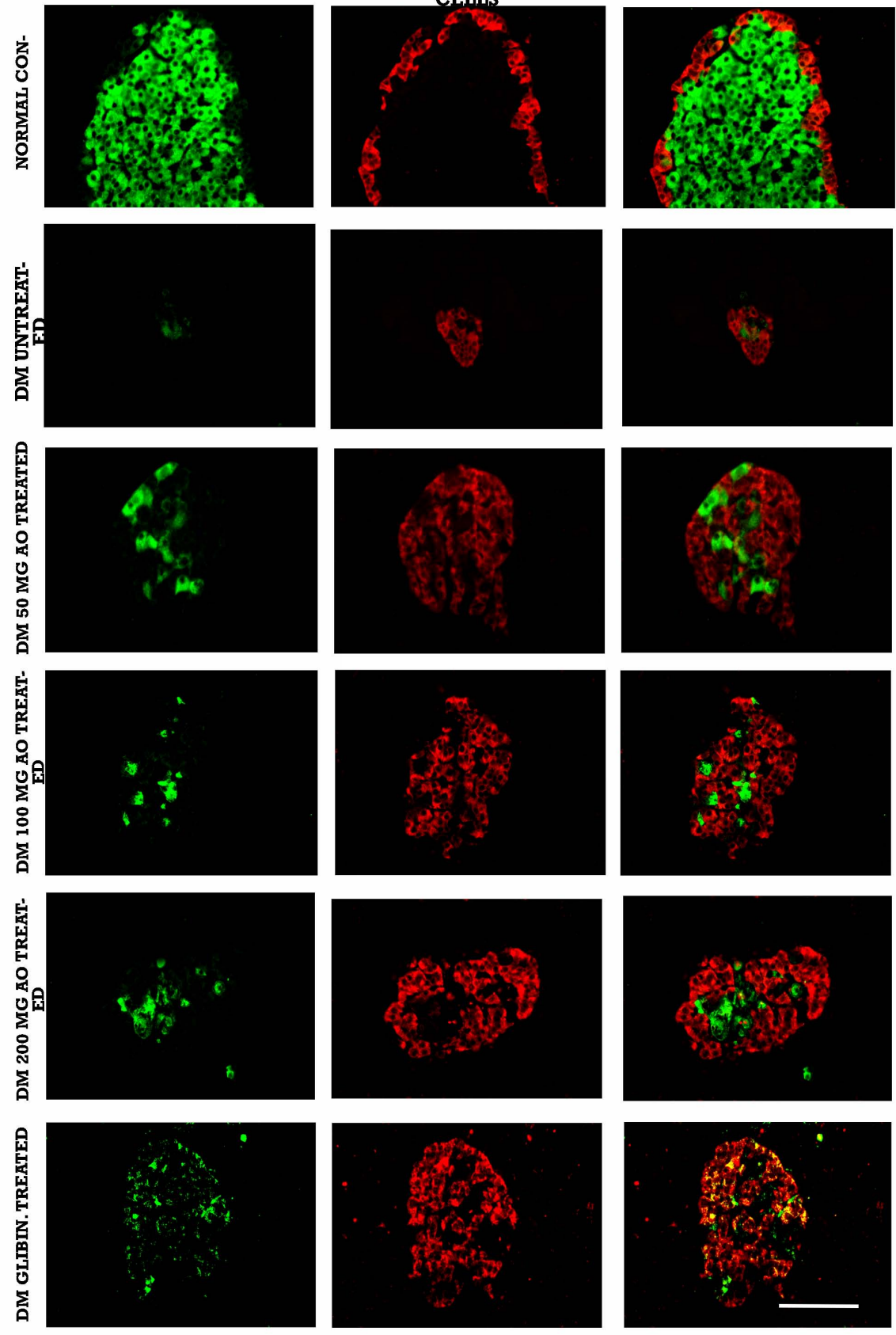

Fig. (2). Immunofluorescence double-labelling images depicting insulin-immunoreactive cells (green) and glucagon-positive cells (red) in the islets of normal, untreated diabetic, and Acridocarpus orientalis (AO)-treated diabetic rats. Note the increase in the number of insulin-positive cells in the islets of AO-treated diabetic compared to untreated diabetic rats. $\mathrm{n}=6$ for each data set. Scale bar $=25 \mu \mathrm{m}$. 



Fig. (3). Bar charts depicting the percentage number of (a) insulin-positive and (b) glucagon-positive cells in the islet of Langerhans of normal, untreated diabetic and Acridocarpus orientalis (AO)-treated diabetic rats. Note the increase in insulin positive cells with a concomitant decrease in glucagon positive cells. Data are presented as: mean \pm SEM, $n=6$ for each data set. $* \mathrm{p}<0.05$, normal versus diabetic and treated versus untreated diabetic rats.

\subsection{Morphology of the Pancreas, Liver, and Kidney}

The histology of $\mathrm{H} \& \mathrm{E}$ stained pancreatic rats islets of either normal control or AO $(50,100$ and $200 \mathrm{mg} / \mathrm{kg}$ body weight $)$ or glibenclamide $(0.25 \mathrm{mg} / \mathrm{kg}$ body weight $)$ treated diabetic rats is displayed in Fig. (4). The structure of the exocrine and endocrine components of the pancreas appears to be intact in normal and in treated, compared to untreated diabetic rats. The number and size of pancreatic islets are significantly smaller in the pancreas of untreated diabetic rats compared to normal and AO-treated rats (Fig. 4). 




Fig. (4). Histopathological images of the pancreas of (a) normal, (b) untreated diabetic, (c) Acridocarpus orientalis (AO) $50 \mathrm{mg} / \mathrm{kg} \mathrm{BW-treated}$ diabetic, (d) AO $100 \mathrm{mg} / \mathrm{kg} \mathrm{BW}$-treated diabetic, (e) AO $200 \mathrm{mg} / \mathrm{kg} \mathrm{BW}$-treated diabetic and (f) glibenclamide-treated rats. Note the intact structure of the exocrine and endocrine (islets: arrows) parts of the pancreas in AO-treated groups compared to untreated diabetic rats. $\mathrm{n}=6$ for each data set. Scale $b a r=200 \mu \mathrm{m}$.

Liver sections showed normal liver cell morphology forming hepatic lobules with radiating cords of hepatocytes from the central vein in both control and AO-treated and untreated diabetic rats (Fig. 5).
Morphology of the kidney of normal control, untreated diabetic and those of diabetic rats treated with either AO (50, 100 and $200 \mathrm{mg} / \mathrm{kg}$ body weight $)$ or glibenclamide $(0.25 \mathrm{mg} / \mathrm{kg}$ body weight) is shown in Fig. (6). Normal control rats, untreated diabetic rats, and diabetic rats treated with $\mathrm{AO}$ or glibenclamide showed almost normal kidney histology.
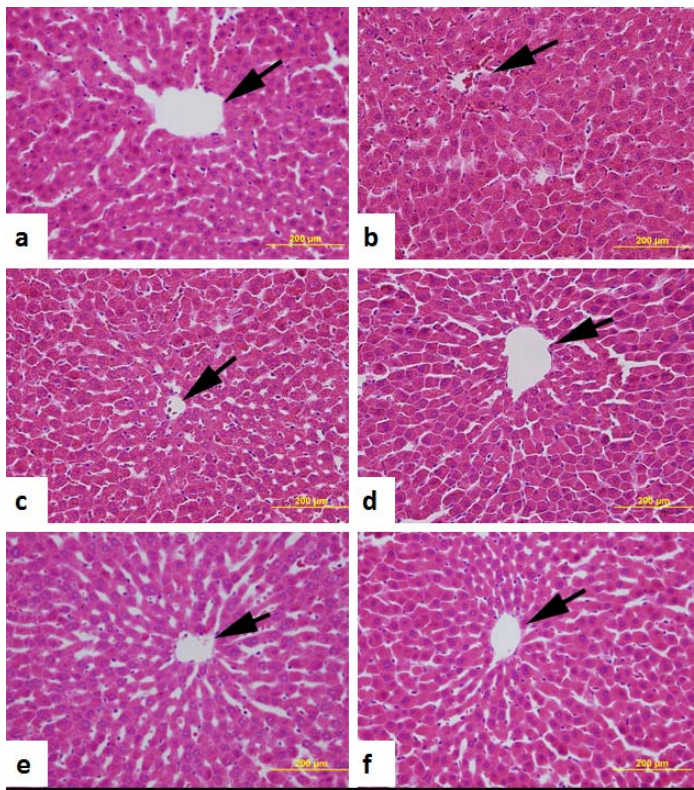

Fig. (5). Light micrographs of the liver of (a) normal, (b) untreated diabetic, (c) Acridocarpus orientalis (AO) $50 \mathrm{mg} / \mathrm{kg} \mathrm{BW}$-treated diabetic, (d) AO $100 \mathrm{mg} / \mathrm{kg} \mathrm{BW}$-treated diabetic, (e) AO $200 \mathrm{mg} / \mathrm{kg} \mathrm{BW}$-treated diabetic and (f) glibenclamide-treated rats. Note that the light microscopy structure of the liver is intact in AO-treated rats when compared to untreated diabetic rats. arrows $=$ central veins. $n=6$ for each data set. Scale bar $=200 \mu \mathrm{m}$. 

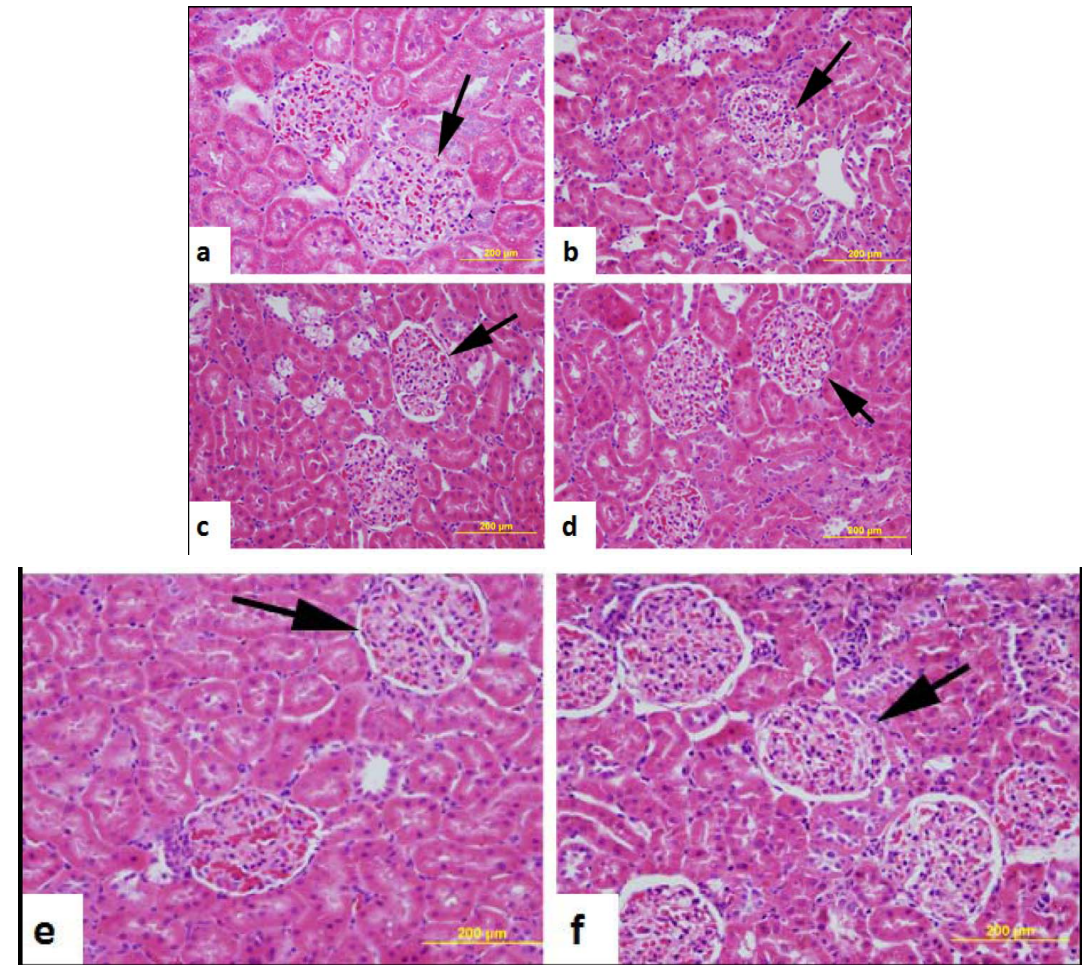

Fig. (6). Light microscope images of the kidney of (a) normal, (b) untreated diabetic, (c) Acridocarpus orientalis (AO) $50 \mathrm{mg} / \mathrm{kg} \mathrm{BW-treated}$ diabetic, (d) AO $100 \mathrm{mg} / \mathrm{kg} \mathrm{BW}$-treated diabetic, (e) AO $200 \mathrm{mg} / \mathrm{kg} \mathrm{BW}$-treated diabetic and (f) glibenclamide-treated rats. The structure of the kidney is similar to that of a normal rat. arrows $=$ renal corpuscles. $n=6$ for each data set. Scale bar $=200 \mu \mathrm{m}$.

\subsection{Liver and Kidney Functions Tests}

The effect of either AO $(50,100 \& 200 \mathrm{mg} / \mathrm{kg}$ body weight) or glibenclamide $(0.25 \mathrm{mg} / \mathrm{kg} \mathrm{BW})$ treatments on serum aspartate aminotransferase (AST) and alanine aminotransferase (ALT) is shown in Figs. (7a) and (b). No significant change in the levels of AST and ALT between normal and AO-treated and untreated rats was observed. In contrast, there was a significant reduction in total serum bilirubin levels in diabetic rats treated with either AO (100 and $200 \mathrm{mg} / \mathrm{kg} \mathrm{BW}$ ) or glibenclamide (0.25 mg/kg BW) (Fig. 7c).

The effect of $\mathrm{AO}(50,100$ and $200 \mathrm{mg} / \mathrm{kg} \mathrm{BW})$ and glibenclamide $(0.25 \mathrm{mg} / \mathrm{kg} \mathrm{BW})$ treatment on serum creatinine in normal, treated and untreated diabetic rats is shown in Fig. (7d). The data demonstrated that the treatment of diabetic rats with $\mathrm{AO}$ at $200 \mathrm{mg} / \mathrm{kg} \mathrm{BW})$ significantly $(\mathrm{p}<0.05)$ reduced serum creatinine when compared to untreated diabetic rats. The blood urea nitrogen $(\mathrm{BUN})$ level is significantly higher $(\mathrm{p}<$ 0.05 ) in diabetic rats compared to non-diabetic control. BUN level failed to change significantly after treatment with either AO or glibenclamide (Fig. 7e).

\subsection{Serum Insulin and SOD}

The effect of either AO or glibenclamide treatments on serum insulin levels in diabetic rats was investigated to determine whether AO has a secretagogue effect. The results indicated that serum insulin concentration was significantly $(\mathrm{p}$ $<0.05$ ) elevated in glibenclamide-treated, but not in AOtreated diabetic rats, compared to untreated diabetic rats (Fig. 8a).

We also examine the effect of AO $(50,100 \& 200 \mathrm{mg} / \mathrm{kg}$ $\mathrm{BW})$ and glibenclamide $(0.25 \mathrm{mg} / \mathrm{kg} \mathrm{BW})$ on serum SOD levels in normal, untreated and treated diabetic rats to determine whether $\mathrm{AO}$ can increase the endogenous antioxidant pool. Our results showed that AO (100 mg/kg BW) increased serum SOD level significantly $(p<0.05)$ when compared to diabetic rats that have not been treated with either AO or glibenclamide (Fig. 8b). 

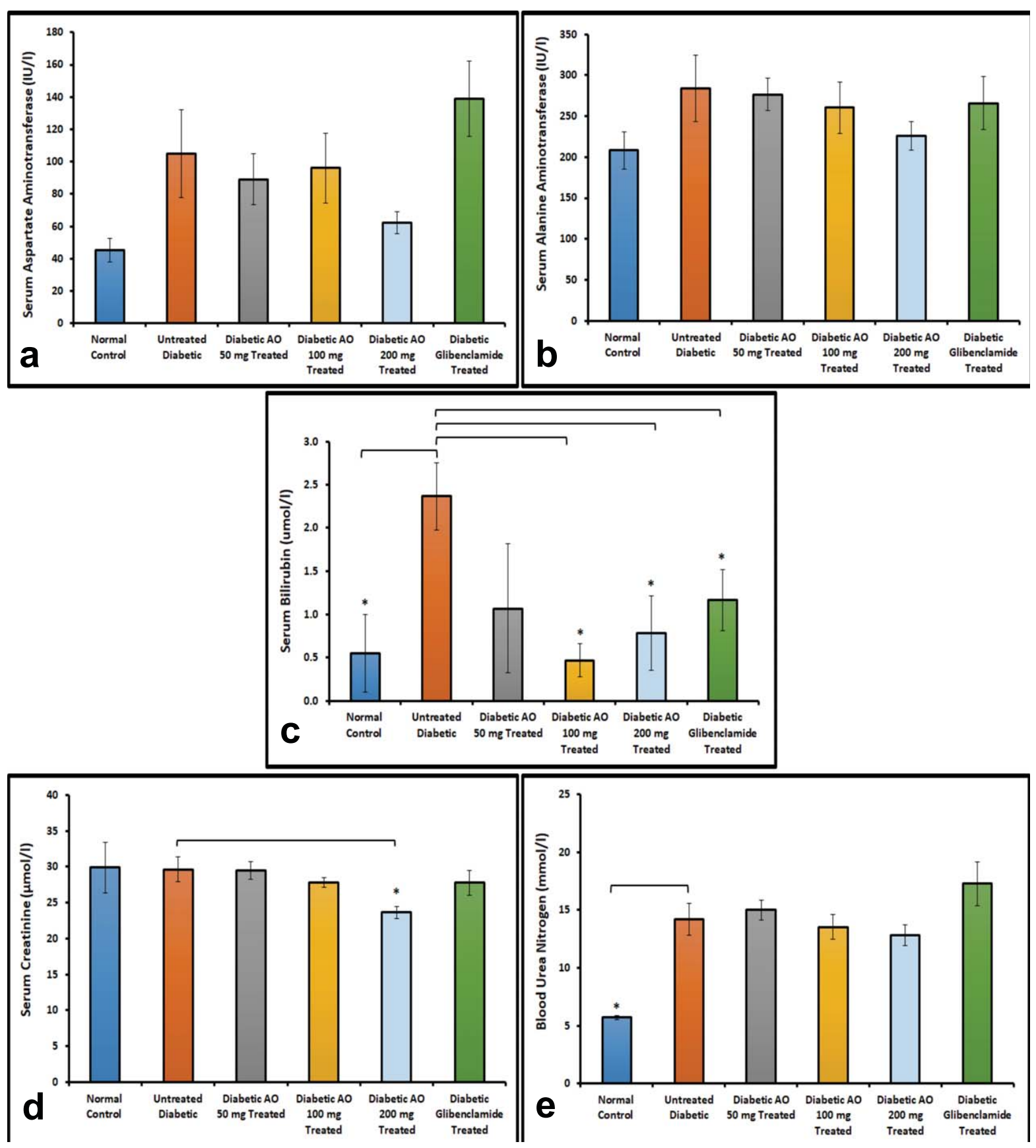

Fig. (7). Bar charts showing the effect of AO on (a-c) liver, and (d-e) kidney function markers in normal, untreated diabetic, AO-treated and glibenclamide-treated diabetic rats. Note that AO and glibenclamide decreased the serum bilirubin level in diabetic rats, while the highest dose of AO significantly reduced the serum creatinine level. Data are presented as: mean \pm SEM, $n=6$ for each data set. $*$ p $<0.05$, normal versus diabetic and treated versus untreated diabetic rats. 

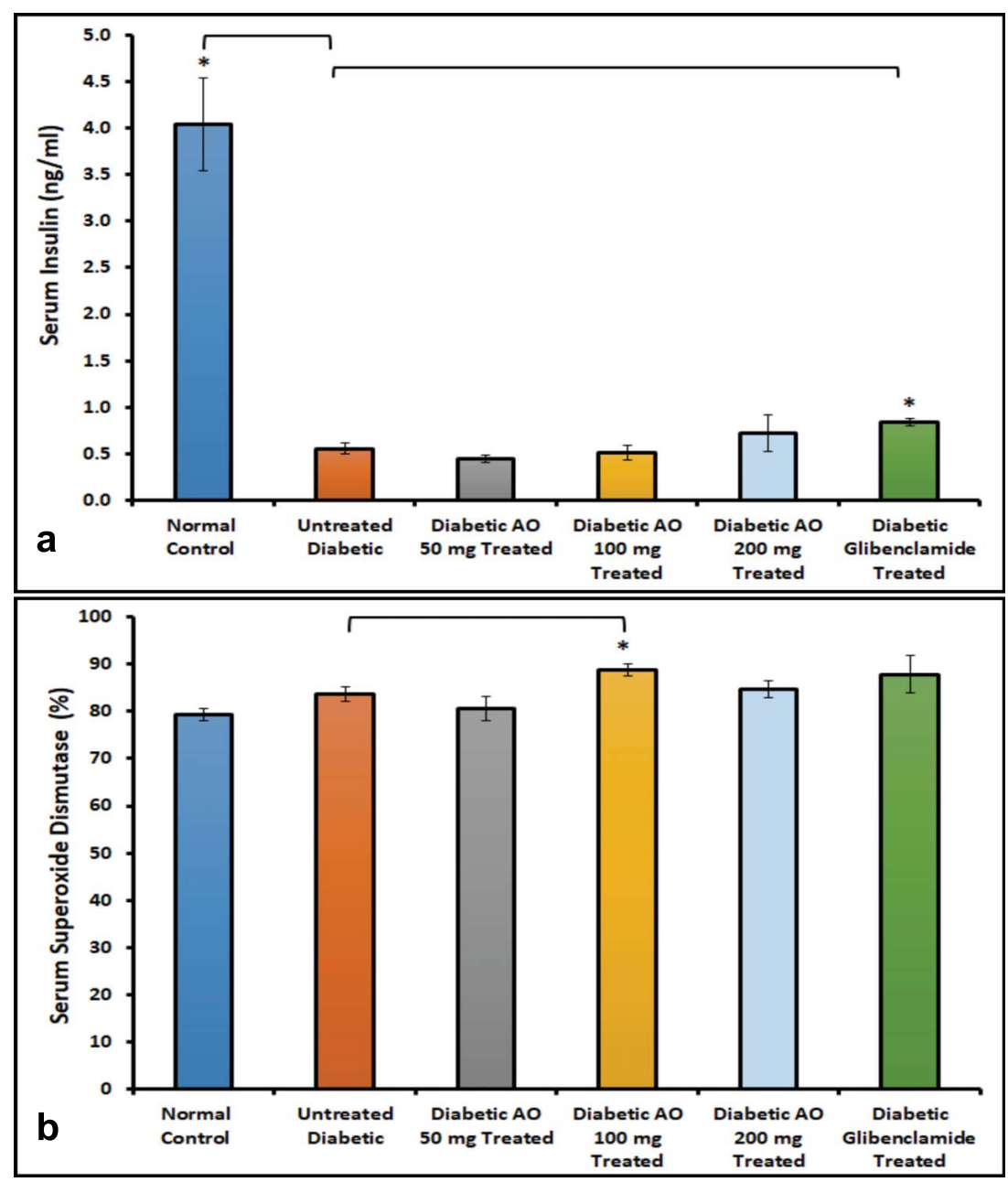

Fig. (8). Bar charts showing the effect of Acridocarpus orientalis (AO) treatment on insulin and superoxide dismutase (SOD) level. Note that glibenclamide but not AO increased the serum insulin level (a). In contrast, AO but not glibenclamide increased SOD level (b). Data are presented as: mean \pm SEM, $n=6$ for each data set. ${ }^{*} \mathrm{p}<0.05$, normal versus diabetic and treated versus untreated diabetic rats.

\section{DISCUSSION}

\subsection{Body Weight, Glucose Level and Glucose Tolerance}

The current study showed that AO plant extract had no effect on body weight gain in diabetic rats. Since this is the first study that examined the effect of $\mathrm{AO}$ on body weight gain in rats, it is difficult to assign a reference point. In addition to the data on the effect of $\mathrm{AO}$ on body weight, the present study showed that at the end of the study, there was no obvious lowering effect of fasting blood glucose after AO treatment in diabetic rats down to the normal value. However, on day 10 of the treatment, there was a significant reduction in the level of fasting blood glucose in diabetic rats treated with AO (100 $\mathrm{mg} / \mathrm{kg} \mathrm{BW}$ ) compared to untreated diabetic rats, but this effect did not persist to the end of the study. The reason for this effect is unknown. It may be due to the quantity of the dose and/or duration of the study. In addition, the intraperitoneal glucose tolerance test (IPGTT) showed that glucose handling was not improved in diabetic rats after treatment with AO. Other herbal extract, such as Momordica charantia, can lower the blood glucose level when administered to diabetic rats [28].

\subsection{Morphological and Immunohistochemical Study}

The results obtained from this study confirmed that the light microscopic structures of the pancreas were near normal, 30 days after treatment with different doses of AO. The overall picture of the protective effects of AO treatment in diabetic rats was evidenced with an improved $\mathrm{H} \& \mathrm{E}$ staining of histological structures in both liver and kidney, which had near normal morphology. The overall effect of AO treatment or its derivative, morin, has been reported to be associated mainly with improving the signs of many diseases such as heart disease, neuropathy, cancer, inflammatory disorders, impaired oxidative stress, liver toxicity, and kidney complaints [29].

There is always an abnormal distribution pattern of both insulin- and glucagon-positive cells within the pancreatic islets of Langerhans in diabetic rats. This abnormal pattern is associated with reduced insulin secreting beta cells and a concomitant increase in the number of glucagon secreting alpha cells $[30,31]$. The number of these beta and alpha cells improved after treatment with AO $200 \mathrm{mg} / \mathrm{kg}$ BW. These findings revealed the protective effect of $\mathrm{AO}$ extract in 
increasing the number of beta cells with a concomitant reduction in the number of glucagon-secreting cells. This observation may be due to the increasing neogenesis of beta cells. The ability of medicinal plants in the initiation of neogenesis has already been reported [28, 32]. The increase in the number of pancreatic beta cells may also be due to a reduction in cell apoptosis. In fact, previous studies [33] showed that active ingredients of AO have anti-apoptotic activity. We did not observe significant increases in the serum insulin level in diabetic rats treated with $\mathrm{AO}$, albeit increases in the number of insulin-positive cells were observed. It is possible that the increase in the number of insulin-producing cells in the islets of Langerhans was not significant to increase the blood concentration of insulin.

However, our study showed a significant reduction in the number of glucagon-positive cells in AO-treated diabetic rats. Since insulin inhibits glucagon, an increased level of insulin will always be associated with a decrease in glucagon concentration. All of these indicate a protective nature of AO on STZ-induced diabetes since glucagon is always upregulated after the onset of diabetes [34].

\subsection{Liver and Kidney Function Tests}

The current study also showed the beneficial effect of AO on liver functions. AST and ALT liver enzymes as markers of liver function demonstrated no significant variations between all study groups. These results mean that $\mathrm{AO}$ is safe and nontoxic to diabetic rat liver. Serum bilirubin was significantly reduced in diabetic rats after treatment with $\mathrm{AO}$ (100 and 200 $\mathrm{mg} / \mathrm{kg} \mathrm{BW}$ ), and glibenclamide. These results revealed that AO has a putative beneficial hepatoprotective effect on diabetic rats. This observation is consistent with the reported antioxidant and anti-lipoxygenase properties of AO [35].

Our study showed that AO treatment has a protective effect on kidney functions after the onset of diabetes, as evidenced by a reduction in the serum level of kidney function markers such as serum creatinine. However, AO failed to alter the BUN level in diabetic rats. These results showed that AO $200 \mathrm{mg} / \mathrm{kg} \mathrm{BW}$ has a beneficial effect on the amelioration of the complications of DM. The ability of AO to protect the kidney and improve on kidney function markers may lie in the fact that AO contains morins, a potent component of flavonoids. Morins have a potent free radical scavenging and anti-lipid peroxidation activities [36, 37]. The fact that AO did not reduce the blood level of BUN may be due to the dosage regimen and the duration of the study.

\subsection{Serum Insulin and SOD}

Our study clearly showed that AO can increase the blood concentration of SOD, a potent endogenous antioxidant. The beneficial action of $\mathrm{AO}$ may be related to its bioactive flavonoid compound morin, which was isolated from aerial samples of AO [14]. Morin is a powerful active compound, which has many functions such as antioxidant, antiinflammatory, neuro-protective, and anti-apoptotic actions [38, 39]. The ability of AO to increase the antioxidant pool in diabetic rat serum may also be due to the polyphenolic compounds of $\mathrm{AO}[40]$.
The effect of AO exhibited in this study may be due to its morin content. Morin, a flavonoid within the larger class of polyphenols, was extracted from AO [14]. In addition, reports have shown that morin is present in osage orange and the leaves of common guava [41]. In previously reported studies, morin inhibited fatty acid synthase, the enzyme responsible for the formation of tissue fat [42]. It also prevents the deposition of amylin in pancreatic islets [43]. Amylin is released with insulin in pancreatic islets, where excessive deposition leads to the development of DM [44]. Other antioxidants, such as tannins, have also been isolated from AO [45]. All of these antioxidants, including morin, may play a role in the mitigation of the signs of DM

\section{CONCLUSION}

In summary, the present study showed the beneficial effects of AO on diabetic rats after 30 days of treatment. AO extract has a beneficial impact on liver and kidney structure and function. In addition, AO increased the antioxidant pool and the number of insulin-secreting beta cells with a concomitant decrease in the number of glucagon-producing cells. All of these observations point to the potential role of AO in the amelioration of the signs of diabetes mellitus. Since this is the first study on the potential effect of AO on diabetes mellitus, more studies are needed to explore additional potentials of this medicinal plant.

\section{LIMITATION OF THE STUDY}

The effect of $\mathrm{AO}$ on the morphology of the pancreas, liver, and kidney and on hepatic, renal and pancreatic functions was carried out on streptozotocin-induced diabetes. This model of $\mathrm{DM}$ is similar to type $1 \mathrm{DM}$ rather than type $2 \mathrm{DM}$. Streptozotocin causes severe destruction of pancreatic beta cells [46], a type that may not completely resemble those seen in human models of DM. Moreover, a higher dose regimen may have a more profound benefit in this animal model.

\section{LIST OF ABBREVIATIONS}

$\begin{array}{ll}\text { DM } & =\text { Diabetes Mellitus. } \\ \text { AO } & =\text { Acridocarpus orientalis. } \\ \text { BW } & =\text { Body Weight. } \\ \text { IDF } & =\text { International Diabetes Federation. } \\ \text { SOD } & =\text { Superoxide Dismutase. } \\ \text { O2: } & =\text { Superoxide Anion. } \\ \text { IPGTT } & =\text { Intraperitoneal Glucose Tolerance Test. } \\ \text { H \& E } & =\text { Haematoxylin and Eosin. } \\ \text { AST } & =\text { Aspartate Aminotransferase. } \\ \text { ALT } & =\text { Alanine Aminotransferase. }\end{array}$

\section{AUTHOR'S CONTRIBUTIONS}

ML, TK, EA, ARP, CD planned the experiment, analyzed data and wrote the manuscript, ML, ARP and CD performed the experiments and ML, SM, EA analyzed data and finalized the manuscript. All the authors approved the final version of the manuscript. 


\section{ETHICS APPROVAL AND CONSENT TO PARTI- CIPATE}

This study has been approved by ethic committee of the College of Medicine \& Health Sciences, United Arab Emirates University, UAE, (Ethical clearance number: A2-R07).

\section{HUMAN AND ANIMAL RIGHTS}

No humans were used. The reported experiments on animals were in accordance of Animal Research Group guidelines for the care and use of laboratory animals (College of Medicine \& Health Sciences, United Arab Emirates University, UAE).

\section{CONSENT FOR PUBLICATION}

Not applicable.

\section{AVAILABILITY OF DATA AND MATERIALS}

Not applicable.

\section{FUNDING}

The project was funded by UAEU UPAR Grant \# 31S163), and research grants from the College of Medicine \& Health Sciences (NP-15-41) UAE.

\section{CONFLICT OF INTEREST}

The authors declare no conflict of interest, financial or otherwise.

\section{ACKNOWLEDGEMENTS}

The authors are grateful to the Department of Biology, College of Science, Department of Anatomy, College of Medicine \& Health Sciences, and the UAE University for creating an environment that encourages research.

\section{REFERENCES}

[1] ATLAS. IDF. "IDF Diabetes Atlas; International Diabetes Federation: Brussels, 2013.

[2] Diagnosis and classification of diabetes mellitus. Diabetes Care, 2004, 27(Suppl. 1), S5-S10.

[http://dx.doi.org/10.2337/diacare.27.2007.S5] [PMID: 14693921]

[3] Adeghate, E.; Schattner, P.; Dunn, E. An update on the etiology and epidemiology of diabetes mellitus. Ann. N. Y. Acad. Sci., 2006, 1084, $1-29$.

[http://dx.doi.org/10.1196/annals.1372.029] [PMID: 17151290]

[4] van Vliet-Ostaptchouk, J.V.; Snieder, H.; Lagou, V. Gene-lifestyle interactions in obesity. Curr. Nutr. Rep., 2012, 1, 184-196. [http://dx.doi.org/10.1007/s13668-012-0022-2] [PMID: 24392269]

[5] Noctor, E.; Dunne, F.P. Type 2 diabetes after gestational diabetes: The influence of changing diagnostic criteria. World J. Diabetes, 2015, 6(2), 234-244.

[http://dx.doi.org/10.4239/wjd.v6.i2.234] [PMID: 25789105]

[6] D'Souza, A.; Howarth, F.C.; Yanni, J.; Dobrzynski, H.; Boyett, M.R.; Adeghate, E.; Bidasee, K.R.; Singh, J. Chronic effects of mild hyperglycaemia on left ventricle transcriptional profile and structural remodelling in the spontaneously type 2 diabetic Goto-Kakizaki rat. Heart Fail. Rev., 2014, 19(1), 65-74.

[http://dx.doi.org/10.1007/s10741-013-9376-9] [PMID: 23430124]

[7] Lotfy, M.; Adeghate, J.; Kalasz, H.; Singh, J.; Adeghate, E. Chronic complications of diabetes mellitus: a mini review. Curr. Diabetes Rev., 2017, 13(1), 3-10.

[http://dx.doi.org/10.2174/1573399812666151016101622] [PMID: 26472574]

[8] Unnikrishnan, R.; Anjana, R.M.; Mohan, V. Diabetes mellitus and its complications in India. Nat. Rev. Endocrinol., 2016, 12(6), 357-370. [http://dx.doi.org/10.1038/nrendo.2016.53] [PMID: 27080137]

[9] Papatheodorou, K.; Papanas, N.; Banach, M.; Papazoglou, D.; Edmonds, M. Complications of Diabetes 2016. J. Diabetes Res., 2016, 20166989453

[http://dx.doi.org/10.1155/2016/6989453] [PMID: 27822482]

[10] Adeghate, E. The role of diabetes mellitus in the Gulf region. Hamdan Med J, 2012, 212, 1-2.

[http://dx.doi.org/10.7707/hmj.v5i2.145]

[11] Ekor, M. The growing use of herbal medicines: issues relating to adverse reactions and challenges in monitoring safety. Front. Pharmacol., 2014, 4, 177.

[http://dx.doi.org/10.3389/fphar.2013.00177] [PMID: 24454289]

[12] Pan, S.Y.; Litscher, G.; Gao, S.H.; Zhou, S.F.; Yu, Z.L.; Chen, H.Q.; Zhang, S.F.; Tang, M.K.; Sun, J.N.; Ko, K.M. Historical perspective of traditional indigenous medical practices: the current renaissance and conservation of herbal resources. Evid. Based Complement. Alternat. Med., 2014, 2014525340

[http://dx.doi.org/10.1155/2014/525340] [PMID: 24872833]

[13] Ksiksi, T.; Hamza, A.A. Antioxidant, lipoxygenase and histone Deacetylase inhibitory activities of Acridocarpus orientalis from $\mathrm{Al}$ Ain and Oman. Molecules, 2012, 17(11), 12521-12532.

[http://dx.doi.org/10.3390/molecules171112521] [PMID: 23095895]

[14] Hussain, J.; Ali, L.; Khan, A.L.; Rehman, N.U.; Jabeen, F.; Kim, J.S.; Al-Harrasi, A. Isolation and bioactivities of the flavonoids morin and morin-3-O- $\beta$-D-glucopyranoside from Acridocarpus orientalis-A wild Arabian medicinal plant. Molecules, 2014, 19(11), 17763-17772. [http://dx.doi.org/10.3390/molecules191117763] [PMID: 25421414]

[15] Chalut, D. Toxicological risks of herbal remedies. Paediatr. Child Health, 1999, 4(8), 536-538.

[http://dx.doi.org/10.1093/pch/4.8.536] [PMID: 20213001]

[16] Crescioli, G.; Lombardi, N.; Bettiol, A.; Marconi, E.; Risaliti, F.; Bertoni, M.; Menniti Ippolito, F.; Maggini, V.; Gallo, E.; Firenzuoli, F.; Vannacci, A. Acute liver injury following Garcinia cambogia weight-loss supplementation: case series and literature review. Intern. Emerg. Med., 2018, 13(6), 857-872.

[http://dx.doi.org/10.1007/s11739-018-1880-4] [PMID: 29802521]

[17] Howarth, F.C.; Jacobson, M.; Shafiullah, M.; Adeghate, E. Effects of insulin treatment on heart rhythm, body temperature and physical activity in streptozotocin-induced diabetic rat. Clin. Exp. Pharmacol. Physiol., 2006, 33(4), 327-331.

[http://dx.doi.org/10.1111/j.1440-1681.2006.04370.x] [PMID: 16620296]

[18] Lotfy, M.; Singh, J.; Rashed, H.; Tariq, S.; Zilahi, E.; Adeghate, E. Mechanism of the beneficial and protective effects of exenatide in diabetic rats. J. Endocrinol., 2014, 220(3), 291-304.

[http://dx.doi.org/10.1530/JOE-13-0426] [PMID: 24353307]

[19] Lamprianou, S.; Gysemans, C.; Bou Saab, J.; Pontes, H.; Mathieu, C.; Meda, P. Glibenclamide Prevents Diabetes in NOD Mice. PLoS One, 2016, $11(12) \mathrm{e} 0168839$

[http://dx.doi.org/10.1371/journal.pone.0168839] [PMID: 28006000]

[20] Elabadlah, H.; Hameed, R.; D’Souza, C.; Mohsin, S.; Adeghate, E.A. Exogenous Ghrelin Increases Plasma Insulin Level in Diabetic Rats. Biomolecules, 2020, 10(4), 633.

[http://dx.doi.org/10.3390/biom10040633] [PMID: 32325912]

[21] Adeghate, E. Effect of subcutaneous pancreatic tissue transplants on streptozotocin-induced diabetes in rats. II. Endocrine and metabolic functions. Tissue Cell, 1999, 31(1), 73-83.

[http://dx.doi.org/10.1054/tice.1999.0007] [PMID: 10368988]

[22] Adeghate, E.; Donáth, T. Morphological findings in long-term pancreatic tissue transplants in the anterior eye chamber of rats. Pancreas, 1990, 5(3), 298-305.

[http://dx.doi.org/10.1097/00006676-199005000-00009] [PMID: 2188255]

[23] Nemmar, A.; Raza, H.; Subramaniyan, D.; John, A.; Elwasila, M.; Ali, B.H.; Adeghate, E. Evaluation of the pulmonary effects of short-term nose-only cigarette smoke exposure in mice. Exp. Biol. Med. (Maywood), 2012, 237(12), 1449-1456.

[http://dx.doi.org/10.1258/ebm.2012.012103] [PMID: 23354403]

[24] Bastaki, S.M.; Amir, N.; Saeed, T.; Adeghate, E. Effect of diabetes mellitus on vitamin B12, pepsinogen and gastric intrinsic factor levels in rats. Hamdan Med J, 2020, 13, 93-100.

[http://dx.doi.org/10.4103/HMJ.HMJ_62_19]

[25] Adeghate, E.; Saeed, Z.; D’Souza, C.; Tariq, S.; Kalász, H.; Tekes, K.; Adeghate, E.A. Effect of nociceptin on insulin release in normal and diabetic rat pancreas. Cell Tissue Res., 2018, 374(3), 517-529. [http://dx.doi.org/10.1007/s00441-018-2903-1] [PMID: 30112574] 
[26] Kozakiewicz, M.; Rowiński, R.; Kornatowski, M.; Dąbrowski, A.; Kędziora-Kornatowska, K.; Strachecka, A. Relation of Moderate Physical Activity to Blood Markers of Oxidative Stress and Antioxidant Defense in the Elderly. Oxid. Med. Cell. Longev., 2019, 20195123628

[http://dx.doi.org/10.1155/2019/5123628] [PMID: 30886673]

[27] Al-Shamsi, M.; Amin, A.; Adeghate, E. Vitamin E ameliorates some biochemical parameters in normal and diabetic rats. Ann. N. Y. Acad. Sci., 2006, 1084, 411-431.

[http://dx.doi.org/10.1196/annals.1372.033] [PMID: 17151319]

[28] Ahmed, I.; Adeghate, E.; Sharma, A.K.; Pallot, D.J.; Singh, J. Effects of Momordica charantia fruit juice on islet morphology in the pancreas of the streptozotocin-diabetic rat. Diabetes Res. Clin. Pract., 1998, 40(3), 145-151.

[http://dx.doi.org/10.1016/S0168-8227(98)00022-9] [PMID: 9716917]

[29] Choudhury, A.; Chakraborty, I.; Banerjee, T.S.; Vana, D.R.; Adapa, D. Efficacy of morin as a potential therapeutic phytocomponent: Insights into the mechanism of action. Int J Med Res Health Sci, 2017, 6, 175-194.

[30] Adeghate, E.; Fernandez-Cabezudo, M.; Hameed, R.; El-Hasasna, H.; El Wasila, M.; Abbas, T.; Al-Ramadi, B. Orexin-1 receptor colocalizes with pancreatic hormones in islet cells and modulates the outcome of streptozotocin-induced diabetes mellitus. PLoS One, 2010, $5(1) \mathrm{e} 8587$

[http://dx.doi.org/10.1371/journal.pone.0008587] [PMID: 20062799]

[31] Lotfy, M.; Singh, J.; Rashed, H.; Tariq, S.; Zilahi, E.; Adeghate, E. The effect of glucagon-like peptide-1 in the management of diabetes mellitus: cellular and molecular mechanisms. Cell Tissue Res., 2014, $358(2), 343-358$

[http://dx.doi.org/10.1007/s00441-014-1959-9] [PMID: 25115772]

[32] Hosseini, A.; Shafiee-Nick, R.; Ghorbani, A. Pancreatic beta cell protection/regeneration with phytotherapy. Braz. J. Pharm. Sci., 2015, 51, 1-6.

[http://dx.doi.org/10.1590/S1984-82502015000100001]

[33] Sinha, K.; Ghosh, J.; Sil, P.C. Morin and Its Role in Chronic Diseases. Adv. Exp. Med. Biol., 2016, 928, 453-471.

[http://dx.doi.org/10.1007/978-3-319-41334-1 19] [PMID: 27671828]

[34] Al-Shamsi, M.; Amin, A.; Adeghate, E. Vitamin E decreases the hyperglucagonemia of diabetic rats. Ann. N. Y. Acad. Sci., 2006, 1084, 432-441.

[http://dx.doi.org/10.1196/annals.1372.032] [PMID: 17151320]

[35] Ksiksi, T.; Rasheed Palakkott, A. BT Ppoyil S, Alhammadi R. Immature leaves of Acridocarpus orientalis A. Juss. exhibits high antioxidant and anti-LOX properties. Curr. Bioact. Compd., 2017, 13, 144-151.

[http://dx.doi.org/10.2174/1573407213666170113152153]

[36] Kim, S.H.; Park, J.W. Morin hydrate attenuates CSE-induced lipid accumulation, ER stress, and oxidative stress in RPE cells: implications for age-related macular degeneration. Free Radic. Res.,
2019, 53(8), 865-874.

[http://dx.doi.org/10.1080/10715762.2019.1637862]

[PMID:

31257945

[37] Lee, M.H.; Cha, H.J.; Choi, E.O.; Han, M.H.; Kim, S.O.; Kim, G.Y.; Hong, S.H.; Park, C.; Moon, S.K.; Jeong, S.J.; Jeong, M.J.; Kim, W.J.; Choi, Y.H. Antioxidant and cytoprotective effects of morin against hydrogen peroxide-induced oxidative stress are associated with the induction of Nrf-2 $\square$ mediated HO-1 expression in V79-4 Chinese hamster lung fibroblasts. Int. J. Mol. Med., 2017, 39(3), 672-680. [http://dx.doi.org/10.3892/ijmm.2017.2871] [PMID: 28204816]

[38] Veerappan, I.; Sankareswaran, S.K.; Palanisamy, R. Morin Protects Human Respiratory Cells from $\mathrm{PM}_{2.5}$ Induced Genotoxicity by Mitigating ROS and Reverting Altered miRNA Expression. Int. J. Environ. Res. Public Health, 2019, 16(13), 2389. [http://dx.doi.org/10.3390/ijerph16132389] [PMID: 31284452]

[39] Sebastian, N.; Yu, W.C.; Balram, D. Synthesis of aminefunctionalized multi-walled carbon nanotube/3D rose flower-like zinc oxide nanocomposite for sensitive electrochemical detection of flavonoid morin. Anal. Chim. Acta, 2020, 1095, 71-81.

[http://dx.doi.org/10.1016/j.aca.2019.10.026] [PMID: 31864632]

[40] Capitani, N.; Lori, G.; Paoli, P.; Patrussi, L.; Troilo, A.; Baldari, C.T.; Raugei, G.; D'Elios, M.M. LMW-PTP targeting potentiates the effects of drugs used in chronic lymphocytic leukemia therapy. Cancer Cell Int., 2019, 19, 67 .

[http://dx.doi.org/10.1186/s12935-019-0786-1] [PMID: 30948927]

[41] Rattanachaikunsopon, P.; Phumkhachorn, P. Bacteriostatic effect of flavonoids isolated from leaves of Psidium guajava on fish pathogens. Fitoterapia, 2007, 78(6), 434-436.

[http://dx.doi.org/10.1016/j.fitote.2007.03.015] [PMID: 17553634]

[42] Tian, W.X. Inhibition of fatty acid synthase by polyphenols. Curr. Med. Chem., 2006, 13(8), 967-977.

[http://dx.doi.org/10.2174/092986706776361012] [PMID: 16611078]

[43] Noor, H.; Cao, P.; Raleigh, D.P. Morin hydrate inhibits amyloid formation by islet amyloid polypeptide and disaggregates amyloid fibers. Protein Sci., 2012, 21(3), 373-382.

[http://dx.doi.org/10.1002/pro.2023] [PMID: 22238175]

[44] Adeghate, E.; Kalász, H. Amylin analogues in the treatment of diabetes mellitus: medicinal chemistry and structural basis of its function. Open Med. Chem. J., 2011, 5(Suppl. 2), 78-81.

[http://dx.doi.org/10.2174/1874104501105010078] [PMID: 21966328]

[45] Lotfy, M.; Al-Hammadi, R.; Palakkott, A.R.; Yasin, J.; Al-Hammadi, S.; Ksiksi, T. Hepatoprotective potentials of Acridocarpus orientalis in mice. Clin Phytosci, 2020, 6, 1-9.

[http://dx.doi.org/10.1186/s40816-020-00184-x]

[46] Adeghate, E.; Hameed, R.S.; Ponery, A.S.; Tariq, S.; Sheen, R.S.; Shaffiullah, M.; Donáth, T. Streptozotocin causes pancreatic beta cell failure via early and sustained biochemical and cellular alterations. Exp. Clin. Endocrinol. Diabetes, 2010, 118(10), 699-707. [http://dx.doi.org/10.1055/s-0030-1253395] [PMID: 20496316]

This is an open access article distributed under the terms of the Creative Commons Attribution 4.0 International Public License (CC-BY 4.0), a copy of which is available at: https://creativecommons.org/licenses/by/4.0/legalcode. This license permits unrestricted use, distribution, and reproduction in any medium, provided the original author and source are credited. 